\title{
COURT DECISIONS IN WRONGFUL BIRTH CASES AS POSSIBLE DISCRIMINATION AGAINST THE CHILD
}

\author{
A POSSÍVEL DISCRIMINAÇÃO CONTRA A CRIANÇA EM DECISÕES JUDICIAIS DE CASOS DE \\ NASCIMENTO INDESEJADO (“WRONGFUL BIRTH”)
}

Petr Sustek

Martin Šolc ${ }^{2}$

\begin{abstract}
The term wrongful birth denotes a claim brought by the parents of an unwanted child who was conceived or born due to medical negligence. The claims are often dismissed as contradictory to good morals or public order. However, there remains a neglected question whether the court decision to award or dismiss damages could constitute discrimination against the child concerned. While the child is not a party to the litigation, it is nevertheless unacceptable for the court not to take into account the effects of its decision on the child. In the case of award of damages, the court publicly affirms the legitimacy of the parents' need for compensation, that is the fact that the child's birth represents recoverable harm to them. The court decision therefore means a different treatment in respect to other children whose benefits for the family are generally recognized and praised by the society. That might have serious psychological consequences for the child, depriving her or him of the full enjoyment of the right to dignity. This fact constitutes discrimination on the grounds of birth, which can be justified only by very weighty reasons. Such reasons may be arguably given in the case of a child incapable of understanding the meaning of wrongful birth litigation, whose special needs are extremely burdensome on the family. On the other hand, the dismissal of the claim cannot represent a negative discrimination against the child.
\end{abstract}

Keywords: Discrimination. Wrongful birth. International human rights law. Human rights of the child. Convention on the Rights of the Child.
Resumo: O termo "wrongful birth" (nascimento indesejado) denota uma reivindicação trazida pelos pais de uma criança que foi concebida ou nascida devido a negligência médica. As alegações são muitas vezes rejeitadas por serem contrárias à moral ou à ordem pública. Contudo, continua a ser negligenciada a questão de saber se a decisão judicial de procedência ou indeferimento da indenização poderia constituir uma discriminação contra a criança. Embora não seja parte no litígio, é, no entanto, questionável que o tribunal não tome em consideração os efeitos da sua decisão sobre a criança. No caso de procedência do pedido, o tribunal afirma a juridicidade da necessidade de indenização aos pais, ou seja, reconhece o fato de que o nascimento da criança representa um prejuízo indenizável. A decisão judicial significa, portanto, um tratamento diferente em relação a outras crianças cujos benefícios para a família são geralmente reconhecidos e elogiados pela sociedade. Isso pode ter sérias consequências psicológicas para a criança, privando-a do pleno gozo do direito à dignidade. Este fato constitui uma discriminação em razão do nascimento, que só pode ser justificada por razões de peso. Tais razões podem ser discutidas no caso de uma criança incapaz de compreender o significado do litígio de "nascimento indesejado", cujas necessidades especiais são extremamente onerosas para a família. Por outro lado, o indeferimento não pode representar uma discriminação negativa contra a criança.

Palavras-chave: Discriminação. Nascimento indesejado. Direito internacional dos direitos humanos. Direitos humanos da criança. Convenção sobre os Direitos da Criança.

\footnotetext{
Ph.D. in Private Law from the Faculty of Law, Charles University; Doctor in Law from the Faculty of Law, Charles University; Coordinator of the Centre for Medical Law at the Faculty of Law, Charles University; Ovocný trh 5, Prague 1, 116 36, Czech Republic; sustek@prf.cuni.cz

2 Doctor in Law from the Faculty of Law, Charles University; Bachelor in politics and international relations from the Faculty of Social Sciences, Charles University; mart.solc@gmail.com
} 


\section{Introduction}

Since the adoption of the Universal Declaration of Human Rights, ${ }^{3}$ the prohibition of discrimination has been growing in importance as one of the crucial institutes of international law guaranteeing the respect for human rights. A crucial tool to secure the fulfilment of the substantial rights of the weak and marginalized. One of the vulnerable groups under international protection are children, whose human rights are guaranteed - specially to most of the international conventions - in the United Nations Convention on the Rights of the Child, which states in its Article 2 (1): "States Parties shall respect and ensure the rights set forth in the present Convention to each child within their jurisdiction without discrimination of any kind, irrespective of the child's or his or her parent's or legal guardian's race, colour, sex, language, religion, political or other opinion, national, ethnic or social origin, property, disability, birth or other status."

Of many modern issues that could possibly violate children's human rights, several very controversial problems can be found in the realm of medical law and ethics. In this paper we will focus on the legal-philosophical aspect of wrongful birth actions. More specifically, the question whether the court decision in such cases may constitute a discrimination against the concerned child will be examined. We will focus primarily on the European area, and consequently deal with the United Nations' and the Council of Europe's systems of human rights protection, but since the nature of wrongful birth claims is the same across the globe, so should be also the conclusions of the paper.

\section{Discrimination}

The prohibition of discrimination can be found in all the significant international human rights documents. ${ }^{4}$ The Council of Europe embodied the prohibition of discrimination into Article 14 of the Convention for the Protection of Human Rights and Fundamental Freedoms ("European Convention"). It is important and as well symptomatic that the right not to be discriminated under this article was meant to be accessorial, i.e. it can only be applied in the conjunction with another, substantial provision of the European Convention ${ }^{5}$ (Chassagnou, 1999). This reflects the

\footnotetext{
3 Most importantly in its Article 2, according to which "[e]veryone is entitled to all the rights and freedoms set forth in this Declaration, without distinction of any kind, such as race, colour, sex, language, religion, political or other opinion, national or social origin, property, birth or other status ..." This demonstrative enumeration has later crucially inspired many other international documents as well as national constitutions.

4 Apart from the above mentioned Declaration of Human Rights and the Convention on the Rights of the Child, discrimination is explicitly addressed for example in Article 2 (2) of the International Covenant on Economic, Social and Cultural Rights, Articles 2 (2), 24 (1), and 26 of the International Covenant on Civil and Political Rights, and it pervades the Convention on the Rights of Persons with Disabilities as one of its general principles.

5 Protocol No. 12 to the European Convention, entered into force on 1 April 2005, prohibits discrimination not only in relation to the provisions of the European Convention, but to "any right set forth by law." However, the Protocol No. 12 has been ratified only by 19 Council of Europe member states up to this date (Council of Europe).
} 
more general fact that discrimination always consists of unlawful deprivation of a person of her or his substantial right.

Encountering such a prominent institute of international law, we need to question what the essential features of discrimination are. Discrimination may be suitably defined as a different treatment of certain individuals or groups in relation to others where no reasonable distinction can be found between those treated differently. ${ }^{6}$

In a particular case, two questions emerge from this definition. First is as to whether the treatment is or is not different. While such a question might seem trivial in some cases, in others it may be the most difficult to answer. In order to understand this more thoroughly, we need to distinguish direct and indirect form of discrimination (Kühn, 2007). In case of direct discrimination, the legislation, policy or conduct is discriminatory in itself. Indirect discrimination, however, consists of specific discriminatory effects of otherwise neutral cause. Examples of this can be very varied from a building accessible only by a flight of stairs indirectly discriminating the wheelchair users (Hunter, 1992 , p. 130) to intelligence tests that are not culturally understandable to their subjects.

In both above mentioned situations, discrimination actually consists of not differentiating between certain groups of people and their needs. This may be true also in case of indirectly discriminating legal norm which is applied to all its addressees equally while the norm has too broad a scope and thus has unequal effect on the addressees - just because it is applied, in formal terms, equally (Kühn, 2007). That is sometimes referred to as the first subtype of indirect discrimination. The second subtype consists of an exemption from a general rule or practice that has disproportionate effects on a certain group: for example less legal protection for part time employees may be in fact discriminating against women under condition that they form a majority of these employees (Kühn, 2007).

While the second subtype calls for the same treatment, the first subtype of discrimination must be eliminated by establishing an exception. If there is an adequate reason for a different treatment of a certain group, such a different approach should be adopted (Rivers, 2002, p. xlix). The concerned group might have a right to this differentiated treatment, i.e. the right to positive discrimination, but only under the circumstances that not only permit but require the distinction (Alexy, 2002, p. 274).

Now we are confronted with the obvious fact that not all differences in treatment are equal: some may be permissible, some damnable and some necessary. That is the second question arising from the definition of discrimination: is the distinction which constitutes a ground for the different treatment reasonable? European Court of Human Rights ("ECHR") accurately defined criteria that has to be met in order to justify the different treatment. It has to have an "objective and reasonable

\footnotetext{
6 As an example of a dictionary definition of discrimination, the Black's Law Dictionary might be used, according to which discrimination consists in "[a] failure to treat all persons equally where no reasonable distinction can be found between those favored and those not favored" (Black, 1990, p. 467).

7 Although there are probably no intelligence tests free of favouring certain culture's cognitive style (Benson, 2003, p. 56).
} 
justification," in other words it must "pursue a legitimate aim" and, cumulatively, there must be "a reasonable relationship of proportionality between the means employed and the aim sought to be realised" (Chassagnou, 1999, p. 91). Otherwise, the discrimination is constituted.

For the needs of practice, the international documents as well as jurisprudence form "suspect" grounds of discrimination. These grounds are typically to be found in non-exhaustive lists of anti-discrimination norms. When assessing a different treatment based on a "suspect" ground, the court would use much stricter criteria for justification of such treatment (Kühn, 2007).

We can therefore conclude with a more nuanced definition of discrimination: a person is discriminated against either when 1) he or she is deprived of his or her right because 2) he or she is treated differently in respect to other persons 3) on the ground that does not provide an objective and reasonable justification, or, alternatively, when 1) he or she is deprived of his or her right because 2) he or she is treated in the same manner as other persons 3) when there is a compelling, objective and reasonable justification for different treatment.

\section{Wrongful birth}

In general, wrongful birth is a term denoting a medical malpractice claim brought by the parents of an unwanted child who was conceived or born due to medical negligence (Black, 1990, p. 1612). These actions must be distinguished from wrongful life claims that are brought on behalf of a child brought with birth defects (Black, 1990, p. 1613) and which are not subject of this paper.

Wrongful birth cases are usually divided into two types (A. Doležal, 2013, p. 42). Wrongful birth claims in the narrower sense are brought by the parents of an impaired child, alleging that negligent treatment or advice deprived them of the opportunity to avoid conception or terminate the pregnancy (Black, 1990, p. 1612). A medical negligence might have occurred in respect to performance of abortion or prenatal diagnosis, or the doctors might have failed to inform the parents about the embryo's or foetus's diagnosed condition or the related risks (A. Doležal, 2013, p. 42). The term wrongful pregnancy (or conception), on the other hand, is used in the situations when the parents of a healthy child (A. Doležal, 2013, p. 42) sue the medical service (health care) provider for a negligent performance of a sterilization procedure or abortion (Black, 1990, p. 1612), or a failure to provide accurate information about the success or reliability of these procedures (Goold, \& Herring, 2014, p. 93).

In both cases, the child would have never been born had it not been for the breach of contract between the now-parents and the medical service provider. The harm consists of a violation of the parent's rights to self-determination and privacy and also in the effects on their financial situation (Šustek, 2011, p. 348). The parents can therefore claim damages for immaterial (i.e. intangible) harm (the loss of control over one's own life, ${ }^{8}$ pain and inconvenience associated with

8 From a legal-philosophical perspective, this apparently constitutes a compelling case for granting wrongful birth claims, given that a modern medical law (as well as all areas of law) stem significantly from a philosophy of autonomy, ultimately 
pregnancy and giving birth (Goold, \& Herring, 2014, p. 94), mental suffering (Šustek, 2011, p. 349), etc.), material losses (typically maintenance costs, but also loss of profit (Goold, \& Herring, 2014, p. 94)) or both.

From the strictly positivist perspective, the wrongful birth cases are just another medical negligence litigations. ${ }^{9}$ Medical service providers have their civil liability; if their contractual duty is breached, harm is suffered and a causal nexus is established, the plaintiff's claim should be granted (Šustek, 2011, p. 350-351), perhaps with the caveat that the harm, in order to be compensable, must have been foreseeable for the health care provider at the time of wrongful act or omission (Holčapek, 2016, p. 310). After all, without civil liability the incentives to provide proper health care would be weakened and the effectiveness of rules regulating medical services nearly nullified (Holčapek, 2013, p. 250). Wrongful birth claims are sometimes subjected to purely legal criticism (primarily in cases of disabled children when the defendant alleges the lack of causal link: medical negligence caused the birth of the child but not its impaired health condition which has a completely independent cause (Smetánková, 2014, p. 165-166)), but dismissal of the claim on these grounds is not frequent (Smetánková, 2014, p. 178).

The ethical side of the problem is different. Not surprisingly, the wrongful birth concept faces a fierce criticism. Many find it outrageous that a child could be considered a harm to compensate, stressing that every child is a blessing, while others claim that the distinction between a child and above mentioned harms must be made (Goold, \& Herring, 2014, p. 98). Others are concerned that physicians under pressure of possible wrongful birth claims would encourage women to terminate pregnancies when the mother would not be sure or when there would be the slightest suspicion of ailment (Vácha, 2008, p. 112). And there are strong voices warning that the child could be later harmed by learning that their parents claimed for a compensation for them (Goold, \& Herring, 2014, p. 101).

If these and other concerns are to be brought to the courtrooms, the institutes designed to mitigate the harshness of positive law and connect it with the realm of morality must be used. There are three options: good morals, ${ }^{10}$ public order and discrimination. The argumentation against granting the wrongful birth claims usually focuses on its impact on society and even when it highlights possible harm caused to the child, it uses the first two options. ${ }^{11}$ In the next part of the paper, the approaches of jurisprudence of selected European countries will be briefly presented. Then, in the last part of the paper, we will discuss a (hitherto neglected) research question whether the court decision granting or dismissing the wrongful birth claim can have a discriminatory effects on the child concerned.

referring to Kantian conception of autonomy as an intrinsic and defining feature of a human being (Cf. Berg, Appelbaum, Lidz, \& Parker, 2001, p. 22).

9 Obviously, wrongful birth claims, at least when connected with negligent performance of abortion, make any sense only in countries where abortion is legal.

10 Generally based on the assumption that human life is the fundamental interest that should be protected by the law at the very first place, even before ensuring the principle pacta sunt servanda.

11 Cf. McFarlane (1999, p. 114, per Lord Millett), Udale (1983), T. Doležal (2013), Vácha (2008, pp. 111-112). 


\section{Jurisprudence in selected European countries}

In Germany, wrongful birth claims are classified as damages resulting from a breach of duty not different from other civil litigations. Courts usually grant the claims for compensation of immaterial and material harm including loss of profit and maintenance costs (T. Doležal, 2013, p. 7). An example of this approach might be the decision 13 U 134/04, 1 February 2006.

The situation in Austria is more differentiated. Only some claims are classified as damage resulting from a breach of duty (typically claims for qualified material damage but not immaterial damage since according to Austrian courts, pregnancy is not considered a bodily harm (T. Doležal, 2013, p. 7)). The Austrian approach has its roots in the decision 1 Ob 91/99k, 25 May 1999. The Supreme Court concluded in what is known as Bydlinski's argument that when the questions of dignity of a human being are concerned, the right to compensation principles can be applied only in cases when the maintenance costs of the child represent exceptional burden on the parents (Cf. Koziol, 2012, pp. 125-130). This principle has then been repeatedly used by the Supreme Court, for example in the cases 6 Ob 303/02f, 23 October 2003, or 6 Ob 101/06f, 14 September 2006. The Supreme Court also repeats its clarification that the birth of a healthy unwanted child cannot constitute basis of a claim for compensation because of the child's personal value, and that exceptional awarding of damages does not mean a negative assessment of the disabled child but exclusively an attempt of monetary compensation of special maintenance costs (Šustek, 2011, p. 351-352). This approach was confirmed by the decision $9 \mathrm{Ob} 37 / 14 b, 29$ January 2015. In this case the problem was that after a sterilization, the woman gave birth to a healthy child. The birth of the child constituted a financial burden for the family. The Supreme Court repeated that the birth of a healthy child is not a damage. A compensation for damages may only be awarded in case of birth of a disabled child or in case that the birth of a healthy child would constitute a financial burden for the family represented by the maintenance costs. Such a financial burden shall only be compensated in a situation threatening plaintiff's personal situation and the security of livelihood.

The crucial ruling for the contemporary situation in the United Kingdom is McFarlane and Another v Tayside Health Board (1999). The House of Lords decided that damages were not recoverable by the parents of a healthy child born as a result of a negligent sterilisation. The plaintiff Mrs McFarlane was awarded compensation for her pain and suffering in pregnancy and immediately consequential financial losses; however, the compensation of the costs of raising an unwanted healthy child would no longer be allowed, being considered an irrecoverable economic loss. After McFarlane, later cases have held that the additional cost of raising an unwanted disabled child over and above the normal costs of having a child will be compensated. ${ }^{12}$

\footnotetext{
12 E.g. Parkinson v St James and Seacroft University Hospital NHS Trust (2001).
} 


\section{The analysis of wrongful birth claims in respect to discrimination}

First it needs to be clarified that even though in wrongful birth cases the child is not party to the litigation, it is nevertheless unacceptable for the court not to take into account the effects of its decision on the child. According to the concept of therapeutic jurisprudence, the law can be understood as a social force that brings about either therapeutic or anti-therapeutic consequences for individuals, while, of course, the therapeutic effects should be maximized and vice versa (Hensel, 2005, p. 163). This demand can hardly be rejected. It may seemingly fit rather in the concept of distributive justice which aims for a just distribution of costs and benefits in society (Goold, \& Herring, 2014, p. 103) than corrective justice that through liability rectifies the injustice inflicted by one person on another (Weinrib, 2002, p. 349). However, even within the realm of corrective justice the court ". . must decide whether recognition of a cause of action would do more harm than good" (Kelley, 1979, p. 928). ${ }^{13}$ In addition, damages are not awarded out of nowhere: there must be paid by someone, who will then often, in effect, spread such loss among the society as a whole (e.g. by compulsory insurance of health care providers). It is highly beneficial for such system not only to allow claims which are worthy of it, but also to reject those which are not (Holčapek, 2011, pp. 24-25).

It is imaginable that both basic options of a court decision in wrongful birth cases, i.e. granting the claim or dismissal of it, could constitute discrimination against the child. If any of these cases indeed constituted discrimination, it would be discrimination on grounds of birth which is explicitly prohibited by the majority of international human rights documents including Article 2 (1) of the Convention on the Rights of the Child ${ }^{14}$ and Article 14 of the European Convention. ${ }^{15,16}$ Typically, the discrimination on the grounds of birth in practice refers to one's status as born out of wedlock (Maldonado, 2011), but could also refer to the status of being adopted (Handbook, 2011, p. 116) or any other resulting from the circumstances of one's birth. According to the ECHR case-law, ${ }^{17}$

\footnotetext{
13 The principle of taking the child's interests into account is reinforced by the provision of Article 3 (1) of the Convention on the Rights of the Child which states: "In all actions concerning children, whether undertaken by public or private social welfare institutions, courts of law, administrative authorities or legislative bodies, the best interests of the child shall be a primary consideration,"

14 Article 2 (1) of the Convention on the Rights of the Child states: "States Parties shall respect and ensure the rights set forth in the present Convention to each child within their jurisdiction without discrimination of any kind, irrespective of the child's or his or her parent's or legal guardian's race, colour, sex, language, religion, political or other opinion, national, ethnic or social origin, property, disability, birth or other status."

15 Article 14 of the European Convention states: "The enjoyment of the rights and freedoms set forth in this Convention shall be secured without discrimination on any ground such as sex, race, colour, language, religion, political or other opinion, national or social origin, association with a national minority, property, birth or other status."

16 From other international law provisions explicitly prohibiting discrimination on grounds of birth we shall name Article 2 of the Declaration on Human Rights, Article 2 (2) of the International Covenant on Economic, Social and Cultural Rights or Articles 2 (2), 24 (1) and 26 of the International Covenant on Civil and Political Rights.

17 ECHR decided for example in the following cases of alleged discrimination on the grounds of birth: Mazurek v France (No. 34406/97), 1 February 2000, Sommerfeld v Germany (No. 31871/96), 8 July 2003, Sahin v Germany (No. 30943/96), 8 July 2003, Camp and Bourimi v The Netherlands (No. 28369/95), 3 October 2000.
} 
discrimination on the grounds of birth is submitted to the "very weighty reasons" test (Cf. Sommerfeld, 2003), given that children have no control over the circumstances of their birth. ${ }^{18}$

In case of wrongful birth claims where children with disabilities are concerned, the possible discrimination would also be constituted on the grounds of disability as explicitly prohibited in Article 2 (1) of the Convention on the Rights of the Child or the Convention on the Rights of Persons with Disabilities.

Now we will proceed to examination of possible court decisions with respect to their potential discriminative effects. First we will discuss the situation when the court awards damages, then we will focus on the opposite alternative. We will not consider the possibility of a partial award of damages, since in that case the arguments for and against awarding damages and dismissing the claim can be simply applied together reciprocally.

a) Negative discrimination caused by award of damages

There are serious concerns that the child can be harmed by learning that his or her parents wanted to be compensated for her or his existence (Cf. Goold, \& Herrin, 2014, p. 101), and if the court affirms the legitimacy of such claim by awarding damages, the child can arguably perceive it as a kind of denial from the society as well. Even though the relevancy of these worries is not scientifically confirmed (which is not at all surprising given the relatively low number of cases and their distribution in many countries), they cannot be easily ignored.

If these concerns are justified, as we will discuss below, the child's right to dignity would be at stake. Dignity, supposedly alongside with life and self-determination, may well be considered one of leading principles of contemporary human rights law. ${ }^{19}$ The Convention on the Rights of the Child states in its preamble that it is based among other values on the "recognition of the inherent dignity" and "worth of the human person." Article 2 (1) of the Convention on the Rights of the Child clearly prohibits all kinds of discrimination, explicitly naming discrimination on the grounds of birth. ${ }^{20}$ With regards to disabled children, the Convention on the Rights of the Child specifically stresses their right to ". . . a full and decent life, in conditions which ensure dignity. .."

Dignity is, however, a significantly vague term. There are many different understandings of it, but in the basics of them all, there is overlapping consensus that dignity is connected with the intrinsic worth every human being has merely by being human (McCruden, 2008, p. 679). It is not

\footnotetext{
18 In the case of a person born out of wedlock, Mazurek v France, ECHR decided that while preserving the traditional family is a legitimate aim, it cannot be proportionally achieved by penalising the child who has no control over the circumstances of their birth (Mazurek, 2000).

19 Here we can emphasise the crucial role of dignity for example in the Declaration of Human Rights or the European Convention.

20 Article 2 (1) of the Convention on the Rights of the Child: "States Parties shall respect and ensure the rights set forth in the present Convention to each child within their jurisdiction without discrimination of any kind, irrespective of the child's or his or her parent's or legal guardian's race, colour, sex, language, religion, political or other opinion, national, ethnic or social origin, property, disability, birth or other status."
} 
clear how exactly this intrinsic value can be defined; however, Kantian concept of dignity as a value that cannot be expressed in money terms (Cf. Barroso, 2012, p. 362) can be useful. For practical reasons, human life can be given certain "price" in well-defined context, for example rationalization of health care or damages in wrongful death cases. ${ }^{21}$ However, this never represents the full value of life. In both above mentioned examples, we can sense that the amount of money is always too low: if the situation was better, there would be more resources to be spent on a patient and those who lost a loved one would be awarded something better than money. Putting price on life seems like a desperate effort to get as close to the incomparable value of human life as it is possible under current circumstances, by the most practical and yet absolutely insufficient mean, that is money.

In case of wrongful birth claims, however, this logic turns out to go against the very basis of the traditional understanding of the value of children and human life itself: it may seem that the parents wish to be compensated as much as possible for something that excludes the possibility of full compensation, i.e. the change of their lives caused by the child.

A very important argument in favour of awarding wrongful birth claims denounces this line of thought and insists that it is crucial to distinguish between the benefits and costs of raising the child. The parents by no means sue for the existence of the child, but for all the distress and financial costs of pregnancy, birth and parenthood (Cf. Goold, \& Herring, 2014, p. 101). If this argument is justifiable, the dignity of the child would not necessarily be violated.

We are now facing the question whether this argument has logical consistency. A person can, indeed, have ambivalent relation to a certain situation, thing or person. However, it is normally presumed that determining whether something is rather beneficial or harming is, at least in clearly defined context and at least theoretically, possible. The law of torts is based on common experience that certain situations are generally harming for people in certain position. The injury usually brings more harm than good to the injured, otherwise it would not be considered "injury" in ordinary parlance. It might well be possible that thanks to the injury, the person would find a husband in the hospital or otherwise will be largely benefited by the event; however, this is rather an exception to the general rule, and, even more importantly, it is a result of a too complex series of consequences to have legal relevancy. The value of human life is embodied into law, among others, by the presumption that life is better than death. Arguably, this can be in certain cases otherwise, but since the two options are mutually exclusive, they cannot be at the same time equally beneficial. If someone would publicly state that death of his family member meant a great good to him, we would not only consider it tasteless, but also logically incoherent with the claim for damages for psychological suffering.

${ }_{21}$ Damages in wrongful death cases are, however, intended to reimburse the emotional distress of the family and friends, not the loss of life of the deceased. 
This line of reasoning is connected with the question of the main function of tort law. We were now discussing mainly the reparation of inflicted harm. If we choose a preventive function to be primary, award of damages would make sense, since it can deter medical professionals from conducting their duties negligently (however, we still need to take into account their possible inclination to encourage abortions rather than risking wrongful birth actions).

It seems, then, that parents can very hardly claim both happiness for having the child and damages for what is inevitably connected with raising the child. It can be argued that parents once showed the willingness to raise the child, implying the child is rather beneficial than harming to them (even if it was for the sense of fulfilment of a certain perceived duty), because they could have put up the child for adoption. The law, of course, does not expect the parents to do it, and for that reason it would be very questionable to consider not doing so an interruption of the causal nexus between the medical negligence and the harm. ${ }^{22}$ From a logical perspective, however, the claim for recovering the maintenance costs after choosing to raise the child is contradictio in adjecto. The plaintiff either claims for a compensation for something she or he does not really perceive as a harm (thus seeks rather the source of income than compensation), or publicly proclaims that the child represents harm. ${ }^{23}$ In other words, the claim for compensation is either groundless, or awarding the claim would be capable of harming the child's dignity. ${ }^{24}$

This line of reasoning is connected with the question of the main function of tort law. It appears that restitutio ad integrum, restoration to original condition, is a basic tort law principle in all European jurisdictions (Smits, 2012, p. 228). In Czech law, restitution to original condition is considered the primary way of compensating damages. ${ }^{25}$ This approach is obviously based on the assumption that pecuniary compensation is the best available remedy, but the ideal remedy would consist of elimination of the wrong. In wrongful birth cases, of course, restitution to original condi-

\footnotetext{
22 Similar argumentation by Goold and Herring in respect to not aborting the baby after failed sterilisation: "It is clear from the case law that a woman is not expected to have an abortion, and a failure to do so cannot constitute an intervening act that would become the cause of the harm" (Goold, \& Herring, 2014, p. 95-96).

23 In this argumentation, we presume that the "benefits-harms ratio" of raising the child can be determined not only theoretically, but also practically (however only approximately). A different approach was chosen by Lord David Hope in his interesting argument against awarding damages in McFarlane and Another v. Tayside Health Board. According to Lord Hope, burdens of raising a child can be estimated, but benefits of a child are incalculable, and therefore incommensurate with the costs. For that reason, it is better to assume that benefits and burdens are in equilibrium and no award is needed. "(It is not) fair, just and reasonable to leave these benefits out, and to do so would mean that the parents were over-paid" (McFarlane, 1999, p. 97, per Lord Hope).

24 Lon L. Fuller in his famous work The Morality of Law distinguishes between logical incoherency and what we may call teleological incoherency of legal norms. Logically inconsistent norms are not in accordance with the law of noncontradiction, in other words they state both A and non-A. However, some norms are logically coherent but they do not reflect any reasonable legislative purpose (for example they make some behaviour compulsory and prohibited at the same time, which is logically possible but probably very unreasonable). In this context, we may consider the claim for damages in wrongful birth case logically incoherent if the child is beneficial to the parents. Award of damages would be in any case teleologically incoherent, because the law and jurisprudence should seek the best interest of the child. (Cf. Fuller, 1998, pp. 65-67).

25 Section 2951 (1) of Act No. 89/2012 Coll., Civil Code: "Damage is compensated by the restoration to the original state. If this is not reasonably possible, or if so requested by the victim, damage is payable in money."
} 
tion is not possible, since it would mean the nonexistence of the child. ${ }^{26}$ This illustrates quite well the relation between harm and compensation in wrongful birth claims.

Discrimination resulting in the denial of dignity is particularly serious when the victim realizes and suffers from the situation. The discrimination constituted by the court decision in wrongful birth cases would then primarily consist of harming the child's sense of self-worth.

The fact that the parents of the child felt they need to be compensated for alleged harms resulting from the child's birth - and the state authority represented by the court - may leave certain mark of "exclusion" on the child, or, in other words, stigmatize her or him. It is well known that stigmatization may have a profound impact on a person's well-being; as the labelling theory shows, negative labels are capable of profoundly distorting one's self-concept and influencing one's way of life. ${ }^{27}$

In context of wrongful birth cases, we may think of several ways the child can be harmed by the stigma of "unwantedness". Wrongful birth cases are usually very attractive to the media, and if the child's identity would be disclosed, the memory of it can be evoked by the people who create the social environment of the child several years later. Given the social stigma related to adoption (Cf. Wegar, 2000, p. 363), it can be presumed that situation would be similar or worse in the case of unwanted child. The people forming the social environment of the child (such as teachers and classmates, coaches and children in sport clubs, "next-door friends" or, when the child grows up, even the colleagues) can be expected to react with the mixture of aversion and unwelcomed expressions of sympathy. These reactions would be probably the strongest when the child is in the most vulnerable age, being very sensitive to his or her social position. The stigmatization is likely to be the more serious the more the child is disabled. ${ }^{28}$ While it may be argued that this problem concerns discrimination caused not by the wrongful birth litigation but by social intolerance, the court should be aware of the possibility of such consequences of its decision.

However, even if the information of the awarded damages never reaches anyone's but the child's ears, a very serious harm can be done. It may disrupt the family relationships, and even if there is no conflict on the surface, the child may be in serious doubt about her or his meaning to the family. Of course, the fact that the parents sued for wrongful birth does not necessarily imply that they do not love the child. Furthermore, there are relatively many unwanted pregnancies and many of these children are truly loved once they are accepted. ${ }^{29}$ However, after wrongful birth litigations it may be very difficult for the parents to explain to the child the paradox of simultaneous loving and claiming damages.

\footnotetext{
$\overline{26}$ As Dimopoulos and Bagaric (2003) put it, ". . the primary aim of damages is to restore the plaintiff in the position he or she would have been in but for the tort. In the context of wrongful life actions, the original position is death" (p. 61).

27 We can recall the research on the role labelling in education (Cf. Ercole, 2009) or criminal behaviour (Cf. Bernburg, Krohn, \& Rivera, 2006).

28 As Hensel (2005) points out, "[w] hen a mother disavows the worthiness of her child's life in open court, those who lack a first-hand knowledge of the child will naturally trust the mother's judgment" (p. 173).

29 Similar line of argument in McFarlane (1999, p. 75, per Lord Slynn).
} 
An experience of clear identity, security and unconditional love in family during the childhood is very important for establishing a healthy self-esteem, which is so vital to dealing with all kinds of challenges in life. Not only practical legal reasons, but also - and maybe foremost - these psychological needs of a child stand behind the right to identity in Articles $7^{30}$ and $8^{31}$ of the Convention on the Rights of the Child. And for these reasons, for decades there has been a serious psychological research as to at what age and how to disclose to the children the fact they were adopted. Even though adopted children generally do not have a reason to doubt their adoptive parent's willingness to raise them (quite the opposite, as the parents must have undertaken a relatively long procedure to adopt them), they are, compared to other children, at higher risk across several domains including achievement in school or even mental health difficulties (Bramlett, Radel, \& Blumberg, 2007, pp. 554-560). Although many of these problems can be partly attributable to genetic causes, psychological issues cannot be overlooked. Adopted children are disproportionately likely to suffer from identity problems which leads to shame, embarrassment low self-esteem (Barran, \& Pannor, 1993, p. 120) or feelings of guilt (Patricelli, 2015). It is likely that all these issues may afflict a child after successful wrongful birth action, feeling deep shame and guilt as an officially confirmed burden on her or his own family.

In order to build a healthy self-esteem (which is so vital to dealing with all kinds of challenges in life), a child needs to develop a favourable self-concept and clear identity. If her or his self-concept and identity are polluted with insecurity, guilt and shame, the child would probably have serious difficulties with experiencing true intrinsic worth, in other words, would have to struggle with a serious obstacle to experiencing his or her own dignity.

Now we shall address the question whether there is a definable group which is treated differently. Such a group can be, in our case, defined simply as children who were initially unwanted by their parents. There is not identifiable a different treatment that would directly discriminate these children. However, the court decision awarding the damages would represent a public affirmation that these children represent a recoverable harm to their parents, which would in effect constitute an obstacle for them to fully enjoy their right to dignity. Therefore, there would be constituted an indirect discrimination on the "suspect" grounds of birth, which can be justified only by very weighty reasons (Cf. Sommerfeld, 2003). Even though the immaterial harm and maintenance costs may prove very burdensome for some parents, the courts should (in accordance with Article 3 (1) of the Convention on the Rights of the Child) consider very thoroughly the interests of the child which would probably outweigh the needs of the parents.

\footnotetext{
30 Article 7 of the Convention on the Rights of the Child: "The child shall be registered immediately after birth and shall have the right from birth to a name, the right to acquire a nationality and. as far as possible, the right to know and be cared for by his or her parents. The child shall be registered immediately after birth and shall have the right from birth to a name, the right to acquire a nationality and as far as possible, the right to know and be cared for by his or her parents."

31 Article 8 of the Convention on the Rights of the Child: "States Parties undertake to respect the right of the child to preserve his or her identity, including nationality, name and family relations as recognized by law without unlawful interference. Where a child is illegally deprived of some or all of the elements of his or her identity, States Parties shall provide appropriate assistance and protection, with a view to re-establishing speedily his or her identity."
} 
b) Negative discrimination caused by dismissal of damages

Unwanted children indeed are, in certain sense, a vulnerable group. Setting aside possible psychological issues resulting from knowing about their "unwantedness" (which could be, as argued above, seriously strengthened by awarding damages in wrongful birth cases), unwanted children are more likely to live in lower-income families (Cf. Jones, Darroch, \& Henshaw, 2002) or just families with many children and little resources left (Cf. Goold, \& Herring, 2014, p. 101). Children with severe disabilities need sometimes very high maintenance costs which may get the family in serious financial troubles.

According to Article 27 (1) of the Convention on the Rights of the Child, every child has the right ". . . to a standard of living adequate for the child's physical, mental, spiritual, moral and social development."

It can be argued that if the financial problems of the family were solved or at least alleviated, the relationship between the parents and the child could actually be improved (Goold, \& Herring, 2014, p. 101).

The argument may go further and claim that awarding compensations for wrongful birth could in fact reduce the number of abortions. It is not very difficult to imagine a pregnant woman who conceived after sterilization and who desperately seeks some way to be able to feed her child. Knowing that there is a possibility of wrongful birth claim, she may decide not to abort the baby. ${ }^{32}$ The question is whether this effect would outweigh possible pressure on physicians to recommend abortions in fear of litigations.

But regardless the effects on abortion rates, the claim can be made that dismissal of damages would constitute the indirect discrimination of the first subtype, i.e. the fail to offer a special treatment to the vulnerable group which needs it. It is in fact the question whether unwanted children have the right to positive discrimination.

In order to explain this, we would first define the positive discrimination as giving advantage to a certain vulnerable group in order to compensate its vulnerability. ${ }^{33}$ The different treatment in this case consists of the fact that that the child's family is provided with a significant contribution to their financial situation while other families with the same number of children with the same health conditions and with similar socioeconomic position can expect no such help. The only reason for the difference in treatment is the fact that some children are unwanted and their parents publicly claim it. ${ }^{34}$

\footnotetext{
$\overline{32}$ "(Compensation) may in some cases be an encouragement and help to bring up an unplanned child" (Emeh, 1985, p. 1021, per Walker.)

${ }_{33}$ Cambridge dictionary (n.d.) defines positive discrimination as the act of giving advantage to those groups in society that are often treated unfairly because of their race, sex, etc." However, this definition can be broadened to encompass also those groups which are not discriminated against intentionally, just like paraplegics or unwanted children.

34 It could be argued that the child has a right to be born to a prepared family and award of damages in its effects compensate the fact that unwanted children are deprived of this right. It is, however, questionable whether this right should be accepted,
} 
However, the term positive discrimination obviously presumes that the different treatment is rather beneficial than harming. It is necessary to realize the obvious fact that compensation, no matter how beneficial, is not awarded to all unwanted children born to struggling families. As Hensel (2005) accurately puts it,

... assistance is provided only to those willing to openly disavow their self-worth and dignity. ... No matter how compelling the need, or how gross the negligence involved, no assistance will be extended to the family who would have chosen to embrace or simply accept the impaired child prior to his birth. . . Whatever the ultimate result of litigation, those involved are likely to feel abused and diminished rather than empowered and vindicated. (pp. 171-172).

This seems to be too high a price, especially for the child who is not capable of deciding whether to pay it.

The objection can be made that some children would be willing to pay the price when they grow up enough to realize the pros and cons. A partial counter-argument can highlight the fact that the child would probably have not wanted it had it not been for a serious financial distress, which should be fixed by the social security system. ${ }^{35}$ If this system fails, it calls for healing the system, not unsystematic symptoms. However, we can still assume that the discrimination constituted by award of damages could be positive.

Positive discrimination can only be a person's right when the situation not only permits, but requires it (Cf. Alexy, 2002, p. 274). The social security system argument can be made to disprove such requirement. However, even the permissibility of this kind of positive discrimination can be questioned.

The financial situation of the family is not caused by the fact that the child was unwanted. It is undoubtedly true that many people want to avoid the birth of a child because of their unfavourable financial situation, and from the perspective of these parents, the unwanted child indeed means a financial burden. On the other hand, from the perspective of the child the situation is different. This particular child lives with the family with certain socioeconomic status and possibilities regardless of whether he or she was wanted or not. The alternative for the parents is not having this child, but the alternative for this child is non-existence (or life with adoptive family). The fact the child was not wanted does not invade into the child's proprietary rights, but rather into her or his immaterial rights. However, the question may arise why we should consider the psychological distress of the child caused by the fact he or she was not wanted as a justification of compensation while we let other children with different but equally serious issues without noticing. Our previous

if only theoretically. More importantly, unwanted children whose parents did not sue for damages were also born into unprepared (but perhaps more accepting) families.

35 Article 27 (3) of the Convention on the Rights of the Child: "assures to assist parents and others responsible for the child to implement this right and shall in case of need provide material assistance and support programmes, particularly with regard to nutrition, clothing and housing."

Article 27 (4) of the Convention on the Rights of the Child: "parents or other persons having financial responsibility for the child, both within the State Party and from abroad." 
claim that the court should not contribute to the mental suffering of the unwanted child does not imply that different causes of mental suffering are any less severe.

We can conclude that positive discrimination constituted by awarding damages in wrongful birth cases is doubtfully permissible and not required. Therefore, it cannot be a right of any person, hence the dismissal of damages cannot constitute negative discrimination.

\section{Conclusion}

From the strictly positivist perspective, wrongful birth claims are usually not very difficult cases. When the breach of a contractual duty of the medical service provider, the harm and the causal nexus are proven, the plaintiff's claim should usually be granted. However, the ethical concerns are so many and so serious that the claims are often dismissed with a reference to good morals or public order. We examined the research question whether there is also the third possible objection to the claims, that is discriminative effects of the court decision to award damages on the child concerned.

We came to the conclusion that dignity of the child can be seriously harmed by award of damages. Since it is not logically coherent to claim that damages are awarded only for the negative consequences of having a child while the child is rather beneficial to the parents, it is inevitable to conclude that the court, by awarding damages, affirms with all its authority given by the state that the child is a burden and harm to her or his family. Psychological consequences of such a decision for the child can be very serious.

We defined the vulnerable group of unwanted children and showed that award of damages - in its meaning of official and public declaration of the child's harming effects on the family means a different treatment in respect to other children whose benefits for the family are generally recognized and praised by the society. This represents a negative discrimination on the grounds of birth, which needs particularly weighty reasons to be justified.

In most cases, such reasons cannot be identified. However, the harm imposed by discrimination in wrongful birth cases consists mainly of the destructive psychological effects on the child. In cases of children with very severe mental disabilities who are not capable of understanding the meaning of wrongful birth litigation, the harm perceived by the child is none. At the same time, these children's special needs are usually especially burdensome on the family. Even though the financial struggles of these families are not more serious than problems of more accepting parents of equally disabled children and should be primarily addressed by the social security system, this fact - in connection with the lack of harm done to the child - might represent "very weighty reasons" justifying the different treatment. ${ }^{36}$

$\overline{36}$ Here it is appropriate to recall a very similar approach taken by Austrian Supreme Court. 
We therefore further examined the question whether the dismissal of damages could not constitute a negative discrimination against the child. This would mean that the situation of unwanted children require a special treatment, i.e. positive discrimination. However, we concluded that the harm done to the child by awarding damages would probably overweigh any benefits of financial support, and, even more importantly, the financial problems of the families with both wanted and unwanted children should be equally addressed by the social security system. These cases nevertheless deserve special consideration and there might arguably be circumstances in which individual assessment of good morals allows for award of damages by way of an exception from general norm.

\section{References}

1 Ob 91/99k, the decision of the Supreme Court of Austria, 25 May 1999.

6 Ob 101/06f, the decision of the Supreme Court of Austria, 14 September 2006.

$6 \mathrm{Ob} 303 / 02 \mathrm{f}$, the decision of the Supreme Court of Austria, 23 October 2003.

$9 \mathrm{Ob} 37 / 14 b$, the decision of the Supreme Court of Austria, 29 January 2015.

13 U 134/04, the decision of the Oberlandesgericht Karlsruhe, 1 February 2006.

Alexy, R. (2002). A Theory of Constitutional Rights. Oxford, NY: Oxford University Press.

Barran, A., \& Pannor, R. (1993, Spring). Perspectives on Open Adoption. Adoption, 3(1).

Barroso, L. R. (2012). Here, there and everywhere: Human dignity in contemporary law and in the transnational discourse. Boston College International and Comparative Law Review, 35(2), 331-393.

Benson, E. (2003, February). Intelligence across cultures. Monitor on Psychology, 34 (2).

Berg, J. W., Appelbaum, P. S., Lidz, C. W., \& Parker, L. S. (2001). Informed Consent. Legal Theory and Clinical Practice. Oxford, NY: Oxford University Press.

Bernburg, J. G., Krohn, M. D., \& Rivera, C. J. (2006 February). Official Labeling, Criminal Embeddedness, and Subsequent Delinquency. A Longitudinal Test of Labeling Theory. Journal of Research in Crime and Delinquency, 43(1), 67-88.

Black, H. C. (1990). Black's Law Dictionary. 6th. ed. St. Paul: West Publishing Company.

Bramlett, M. D., Radel, L F., \& Blumberg, S. J. (2007, February). The Health and Well-being of Adopted Children. Pediatrics, 119(1).

Cambridge Dictionary. Positive discrimination (n.d.). Retrieved from: http://dictionary.cambridge. org/dictionary/english/positive-discrimination

Camp and Bourimi v. The Netherlands, No. 28369/95, 3 October 2000.

Chassagnou and Others v. France, No. 25088/94, 28331/95, 284343/95, 29 April 1999. 
Council of Europe. Chart of signatures and ratifications of Treaty 177. Retrieved from: http://www. coe.int/en/web/conventions/search-on-treaties/-/conventions/treaty/177/signatures?.p_auth $=0 \mathrm{Kq} 9 \mathrm{rtcm}$

Dimopoulos, P., \& Bagaric, M. (2003). The Moral Status of Wrongful Life Claims. Common Law World Review, 32.

Doležal, A. (2013). Wrongful life, wrongful birth žaloby - etické a právní úvahy. Journal of Medical Law and Bioethics, 3(3), 38-57.

Doležal, T. (2013). Úvod do problematiky "wrongful birth" a "wrongful life" žalob. Journal of Medical Law and Bioethics, 3(3), 4-12.

Emeh v. Kensington and Chelsea and Westminster Area Health Authority, 1 Q.B. 1012, 1985.

Ercole, J. (2009, Spring). Labeling in the Classroom: Teacher Expectations and their Effects on Student's Academic Potential. University of Connecticut Digital Commons. Retrieved from: http:// digitalcommons.uconn.edu/cgi/viewcontent.cgi?.article $=1074 \&$ context $=$ srhonors_theses

Fuller, L. F. (1998). Morálka práva. Praha: OIKOYMENH.

Goold, I., \& Herring, J. (2014). Great Debates in Medical Law and Ethics. London: Palgrave.

Handbook on European non-discrimination law (2011). Luxembourg: Publications Office of the European Union.

Hensel, W. F. (2005, Winter). The Disabling Impact of Wrongful Birth and Wrongful Life Actions. Harvard Civil Rights-Civil Liberties Law Review, 40(1), 141-196.

Holčapek, T. (2011). Dokazovánív medicinskoprávnich sporech. Praha: Wolters Kluwer.

Holčapek, T. (2013). Medical and Health Law in the Czech Republic. In R. G. Beran (Ed.), Legal and Forensic Medicine. Heidelberg: NY: Springer.

Holčapek, T. (2016). Občanskoprávní odpovědnost v medicíně a její uplatňování u českých soudů. Právní rozhledy, (9), 305-311.

Hunter (1992). Indirect Discrimination in the Workplace. Sydney: The Federation Press Pry.

Jones, R. K., Darroch, J. E., \& Henshaw, S. K. (2002, October). Patterns in the socioeconomic characteristics of women obtaining abortions in 2000-2001. Perspectives on Sexual and Reproductive Health, 34(5), 226-235.

Kelley, P. J. (1979). Wrongful Life, Wrongful Birth, and Justice in Tort Law. Washington University Law Quarterly, (4).

Koziol, H. (2012). Basic Questions of Tort Law from a Germanic Perspective. Wien: Jan Sramek Verlag. Kühn, Z. (2007, April 30). Diskriminace v teoretickém a srovnávacím kontextu. Právní fórum. 
Maldonado, S. (2011, April). Illegitimate harm: Law, stigma and discrimination against nonmarital children. Florida Law Review, 63(2).

Mazurek v. France, No. 34406/97, 1 February 2000.

McCruden, C. (2008). Human Dignity and Judicial Interpretation of Human Rights. The European Journal of International Law, 19(4), 655-724.

McFarlane and Another v. Tayside Health Board, The decision of the House of Lords, 1999.

Parkinson v. St JameS and Seacroft University Hospital NHS Trust, EWCA Civ 530, 2001.

Patricelli, K. (2015). Long-Term Issues for The Adopted Child. MentalHelp.net. Retrieved from: https://www.mentalhelp.net/articles/long-term-issues-for-the-adopted-child/

Rivers, J. (2002). A Theory of Constitutional Rights and the British Constitution. In R. Alexy, Theory of Constitutional Rights. Oxford, NY: Oxford University Press.

Sahin v. Germany, No. 30943/96, 8 July 2003.

Smetánková, B. (2014). Bezprávný život: Teoretická koncepce nároků na náhradu škody za újmu plynoucí z narození člověka. In A. Gerloch, \& K. Beran, Funkce a místo právní odpovědnosti v recentním právním řádu. Praha: Leges.

Smits, J. M. (2012). Elgar Encyclopedia of Comparative Law. 2nd. ed. Cheltenham: Edward Elgar Publishing Limited.

Sommerfeld v. Germany, No. 31871/96, 8 July 2003.

Šustek, P. (2011). Ochrana života a zdraví ve Všeobecném občanském zákoníku (Život jako újma?). In J. Dvořák, \& K. Malý, 200 let Všeobecného občanského zákoníku. Praha: Wolters Kluwer.

Udale v. Bloomsbury area health authority, 1 W.L.R. 1098, 1983.

Vácha, M. (2008). Misto, na němž stojíš, je posvátná země. Brno: Cesta.

Wegar, K. (2000 October). Adoption, Family Ideology, and Social Stigma: Bias in Community Attitudes, Adoption Research, and Practice. Family Relations, 49(4), 363-370.

Weinrib, E. J. (2002, Autumn). Corrective Justice in a Nutshell. The University of Toronto Law Journal, 52(4).

Data de submissão: 20 de outubro de 2016 Avaliado em: 15 de janeiro de 2017 (AVALIADOR A) Avaliado em: 31 de janeiro de 2017 (AVALIADOR B)

Aceito em: 11 de abril de 2017 